\title{
Bayesian threshold analysis of litter size in sheep
}

\author{
Análisis de umbral bayesiano del tamaño de la camada en ovejas
}

Análise de limiar bayesiano do tamanho da ninhada em ovinos

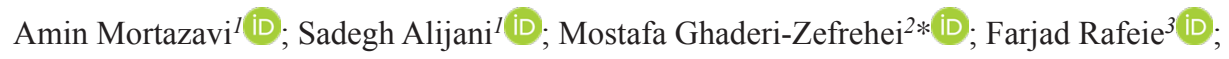 \\ Ali Jafari² ${ }^{2}$; Hamed Amirpour-Najafabadi ${ }^{4}$ (D). \\ ${ }^{1}$ Department of Animal Science, University of Tabriz, Tabriz, Iran. \\ ${ }^{2}$ Department of Animal Science, Yasouj University, Yasouj, Iran. \\ ${ }^{3}$ Department of Agricultural Biotechnology, Faculty of Agricultural Sciences, University of Guilan, Rasht, Iran. \\ ${ }^{4}$ Faculty of Agriculture and Life Sciences, Lincoln University, Lincoln 7647, New Zealand.
}

To cite this article:

Mortazavi A, Alijani S, Ghaderi-Zefrehei M, Rafeie F, Jafari A, Amirpour-Najafabadi H. Bayesian threshold analysis of litter size in sheep. Rev Colomb Cienc Pecu 2022; 35(3): 125-140. DOI: https://doi.org/10.17533/udea.rccp.v35n3a05

\begin{abstract}
Background: Litter size at birth (LSB) is one of the most important economic traits in sheep and could be used in genetic improvement schemes for meat production. LSB is inherently a categorical trait and should be analysed with threshold models. Objective: Bayesian threshold models were used to analyze sheep LSB to estimate genetic parameters. Methods: Data was based on 7,901 LSB records from 14,968 dams and 682 sires collected from 1986 to 2012 at Makouie Sheep Breeding Station in Iran. Means of posterior distributions (MPDs) of LSB's genetic parameters were estimated, and the best-fitted models were selected using the deviance information criterion. Results: In the repeated measurement analysis, the estimated direct and maternal heritabilities, and permanent environmental effect $( \pm \mathrm{SE})$, according to the best-fitted model (model 5), were $0.01(0.010), 0.02(0.014)$, and $0.01(0.011)$, respectively. In the univariate analysis, the best estimates of direct and maternal heritabilities were $0.12(0.064)$ and $0.08(0.045)$, respectively. An increasing trend for direct and maternal heritabilities was observed in parity $2(0.15(0.082)$ and $0.25(0.083)$, respectively). In the bivariate analysis, the best estimates of direct and maternal heritabilities for LSB were $0.03(0.027)$ and $0.22(0.041)$, respectively. The direct and maternal genetic correlations among parities were $0.25(0.054)$ and $0.12(0.021)$, respectively. Conclusions: The results showed a considerable influence of environmental factors on LSB in each parity of sheep; also, statistically different genetic parameters $(p<0.05)$ were obtained from one parity to another, indicating the different and large influences of genetic and environmental factors for each parity.
\end{abstract}

Received: February 9, 2021; accepted: December 1, 2021

*Corresponding author. Yasouj, Iran.P. O. Box: 75914, Fax: +98 741222 4840, Tel: +98 741222 4840. Email: mghaderi@yu.ac.ir, mosmos741@yahoo.com

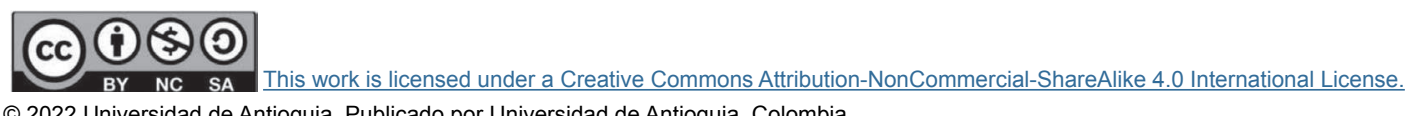

2022 Universidad de Antioquia. Publicado por Universidad de Antioquia, Colombia.

eISSN: 2256-2958

Rev Colomb Cienc Pecu 2022; 35(3, Jul-Sep):125-140

https://doi.org/10.17533/udea.rccp.v35n3a05 
Keywords: bayesian; bivariate analysis; genetic improvement; genetic parameters; heritability; litter size; maternal genetic; sheep; threshold models; univariate analysis.

\section{Resumen}

Antecedentes: El tamaño de la camada al nacer (LSB) es inherentemente un rasgo categórico y debe analizarse con modelos de umbral. El LSB es uno de los rasgos de producción de carne más importantes en las ovejas y podría usarse en esquemas de mejora genética para la producción de carne. Objetivo: Se utilizaron modelos de umbral bayesiano para analizar el tamaño de la camada de ovejas al nacer (LSB) y estimar parámetros genéticos. Métodos: Los datos se basaron en 7.901 registros de LSB de 14.968 ovejas y 682 carneros recolectados de 1986 a 2012 en la estación de cría de ovejas Makouie en Irán. Se estimaron las medias de distribuciones posteriores (MPD) de los parámetros genéticos de LSB y se seleccionaron los modelos mejor ajustados utilizando el criterio de información de desviación. Resultados: En los análisis de medición repetida, la heredabilidad materna y directa estimada y el efecto ambiental permanente $( \pm \mathrm{SE})$, según el modelo mejor ajustado (modelo 5), fueron $0,01(0,010)$, $0,02(0,014)$ y $0,01(0,011)$, respectivamente. En el análisis univariado, las mejores estimaciones de heredabilidad directa y materna fueron $0,12(0,064)$ y $0,08(0,045)$, respectivamente. Se observó una tendencia creciente de heredabilidades directas y maternas en la paridad $2(0,15(0,082)$ y $0,25(0,083)$, respectivamente). En el análisis bivariado, las mejores estimaciones de heredabilidad directa y materna para LSB fueron $0,03(0,027)$ y $0,22(0,041)$, respectivamente. Las correlaciones genéticas directas y maternas entre partos fueron $0,25(0,054)$ y $0,12(0,021)$, respectivamente. Conclusiones: Los resultados mostraron una influencia considerable de los factores ambientales sobre el LSB en cada parto de las ovejas; además, se obtuvieron parámetros genéticos estadísticamente diferentes $(\mathrm{p}<0.05)$ de un parto a otro, indicando las diferentes y grandes influencias de factores genéticos y ambientales para cada parto en ovejas. Los resultados de este estudio se pueden precisar aún más utilizando datos de SNP de todo el genoma sobre diferentes partes para manejar una amplia gama de problemas relacionados con la interacción del entorno genético del rasgo LSB.

Palabras clave: análisis bivariado; análisis univariado; Bayesiano; genética materna; heredabilidad; mejora genética; modelos de umbral; oveja; parámetros genéticos; tamaño de la camada.

\section{Resumo}

Antecedentes: O tamanho da ninhada ao nascer (LSB) é inerentemente uma característica categórica e deve ser analisada com modelos de limiar. LSB é uma das características mais importantes de produção de carne em ovinos e pode ser usado em esquemas de melhoramento genético para a produção de carne. Objetivo: Modelos de limiar bayesiano foram usados para analisar o tamanho da ninhada de ovelhas ao nascer (LSB) para estimar parâmetros genéticos. Métodos: Os dados foram baseados em 7.901 registros LSB de 14.968 ovelhas e 682 carneiros coletados de 1986 a 2012 na Estação de Criação de Ovinos Makouie no Irã. Médias de distribuições posteriores (MPDs) dos parâmetros genéticos de LSB foram estimadas e os modelos mais bem ajustados foram selecionados usando o critério de informação de desvio. Resultados: Nas análises de medidas repetidas, as herdabilidades diretas e maternas estimadas e o efeito do ambiente permanente $( \pm \mathrm{SE})$, de acordo com o modelo mais bem ajustado (modelo 5), foram 0,01 (0,010), 0,02 (0,014) e 0,01 $(0,011)$, respectivamente. Na análise univariada, as melhores estimativas das herdabilidades direta e materna foram $0,12(0,064)$ e $0,08(0,045)$, respectivamente. Uma tendência crescente para as herdabilidades direta e materna foi observada na paridade $2(0,15(0,082)$ e $0,25(0,083)$, respectivamente). $\mathrm{Na}$ análise bivariada, as melhores estimativas de herdabilidades direta e materna para LSB foram $0,03(0,027)$ e $0,22(0,041)$, respectivamente. As correlações genéticas diretas e maternas entre os partos foram $0,25(0,054)$ e $0,12(0,021)$, respectivamente. Conclusões: Os resultados mostraram uma influência considerável dos fatores ambientais na LSB em cada paridade de ovelhas; também, parâmetros genéticos estatisticamente diferentes $(\mathrm{p}<0,05)$ foram obtidos de uma paridade para outra, indicando as diferentes e grandes influências de fatores genéticos e ambientais para cada paridade em ovinos. Os resultados deste estudo podem ser ainda mais definidos usando dados SNPs de todo o genoma em diferentes partes para lidar com uma ampla gama de problemas relacionados à interação do ambiente genético do traço LSB.

Palavras-chave: análise Bayesiana; análise bivariada; análise univariada; genética materna; herdabilidade; melhoramento genético; modelos de limiar; ovelhas; parâmetros genéticos; tamanho da ninhada. 


\section{Introduction}

Even though genetics has a major influence on litter size in sheep, there are many environmental, nutritional and management factors playing a big role in the variation of litter size at birth (LSB) at the farm level. By focusing on some of these crucial factors, it is possible to improve not only litter size but importantly also, other traits such as weaning capacity. In general, increasing birth weight is difficult but still one can manage other factors to improve it slightly, and also to improve litter size viability at birth. The LSB is inherently a categorical trait and should be analysed using threshold models and it is a major determinant of successful reproduction in ewes and includes other sub-traits (ovulation rate, embryo survival, and uterine capacity) (Yazdi et al., 1999). Direct heritability estimates for LSB in sheep are usually low to medium (Hagger et al., 2002). Genetic evaluations for categorical traits, e.g., LSB, are achieved through different methodologies compared to evaluating continuous traits (Abdel-Azim et al., 1999). On the other hand, LSB in sheep can be effectively improved through phenotypic selection, even in small flocks (Casellas et al., 2007). The genes controlling LSB in any parity may differ from another; therefore, each parity must be treated as a different trait (Noguera et al., 2003; Roeche et al., 1995). The Bayesian approach via the Gibbs sampling has been used to estimate genetic parameters of LSB and birth weight, body weight, LSB, carcass traits and visual scores, survival, body condition score, wool shedding, worm resistance, wool and growth traits, and daily gain traits in several sheep populations (Latifi et al., 2017; Yadollahi et al., 2019; Yazdi et al., 1999; Ghavi HosseinZadeh., 2010; Júnior et al., 2017; King et al., 2006; Alves et al., 2016; Vargas Jurado et al.,2016; Ciappesoni et al., 2013; Gowane et al., 2015). The LSB is one of the most important meat production traits in sheep and could be used in genetic improvement schemes for meat production (Olesen et al., 1994).

There are approximately 50 million sheep and 27 breeds in Iran that provide about $42 \%$ of
Iran's protein supply (Vatankhah et al., 2004). In the Middle East of Iran, the fat-tailed sheep, e.g., Makouie, are dominant (Esmailizadeh et al., 2011). Ewes and rams are often kept in the herd up to 7 parities and 5 breeding seasons, respectively. Lambing occurs once a year (late January to March) (Jafari et al., 2012). Even though some studies on Makouie sheep (growth traits, fleece and post-weaning weight, some reproductive traits) have been reported (Jafari et al., 2014; Jafari et al., 2012; Rahimi et al., 2014), very little is known about the genetic attributes of LSB in this breed. Thus, this study aimed to estimate genetic parameters for LSB in Makouie sheep using Bayesian threshold models.

\section{Materials and Methods}

\section{Data preparation}

This study was based on 7,091 LSB records from 14,968 dams and 682 sires collected from 1986 through 2012 at Makouie sheep breeding station, Makou, Iran. The data included the birth date, lambing date, herd, parity, gender, pedigree information and LSB, measured by the number of lambs born per ewe lambing. Due to low numbers of records, the triplets in each parity and total parities, and records in parities $3(\mathrm{n}=904$, $9.8 \%$ of total LSB records) and $4(\mathrm{n}=424,4.5 \%$ of total LSB records) were not considered in this analysis. The twin percentages in parities 1 and 2 were 8.4 and $8.8 \%$, respectively (Table 3 ). The pedigree was prepared using CFC software (Sargolzaei et al., 2006) and its structure is shown in Table 1.

\section{Statistical analysis}

The parameters for data analysis used in the current study are presented in Table 2. Herd, year, and season of lambing, parity, and age of dam were assumed as fixed effects and were included in a multiple logistic regression model (Alison et al., 2001) to determine their effects on LSB. Only herd (45 levels) and year of lambing (17 levels) had significant effect on LSB $(p<0.05)$. Therefore, herd and year were used as fixed effects in the statistical models. 
Table 1. Structure of the Makouie sheep pedigree data.

\begin{tabular}{|c|c|}
\hline Individuals & Number \\
\hline Total animals & 42,783 \\
\hline Evaluated animals & 42,783 \\
\hline Inbred in evaluated animals & 273 \\
\hline Total sires & 682 \\
\hline -Progeny & 11,249 \\
\hline Total dams & 14,968 \\
\hline -Progeny & 27,551 \\
\hline Total inbred animals & 273 \\
\hline Founders & 14,963 \\
\hline -Progeny & 19,823 \\
\hline -Sires & 520 \\
\hline -Progeny & 8,135 \\
\hline -Dams & 10,382 \\
\hline -Progeny & 17,496 \\
\hline -Without progeny & 4061 \\
\hline Total animals with progeny & 15,650 \\
\hline $\begin{array}{l}\text { Total animals without } \\
\text { progeny }\end{array}$ & 27,133 \\
\hline \multicolumn{2}{|l|}{ Inbred animals: } \\
\hline $0.00<\mathrm{F} \leq 0.05$ & 109 \\
\hline $0.05<\mathrm{F} \leq 0.10$ & 33 \\
\hline $0.10<\mathrm{F} \leq 0.15$ & 81 \\
\hline $0.15<\mathrm{F} \leq 0.20$ & 1 \\
\hline $0.20<\mathrm{F} \leq 0.25$ & 49 \\
\hline
\end{tabular}

Table 2. Parameters for data analysis.

\begin{tabular}{lc}
\hline Parameter & Value \\
\hline Number of samples & 200,000 \\
Burn-in period & 10,000 \\
Thinning interval & 100 \\
Number of records in bivariate analysis & 6,010 \\
Number of records in repeated measurement & 7,901 \\
analysis & \\
Number of records in univariate analysis: & \\
$\quad$ Parity 1 & 5,458 \\
$\quad$ Parity 2 & 2,443 \\
\hline
\end{tabular}

\section{Repeated threshold models}

In the repeated-model analysis, the LSBs in all parities were considered simultaneously in the analysis. The data were analysed using six models, by considering different random effects (additive, maternal, and permanent environmental effects) and covariance between direct and maternal genetic effects. The models used were as follows:

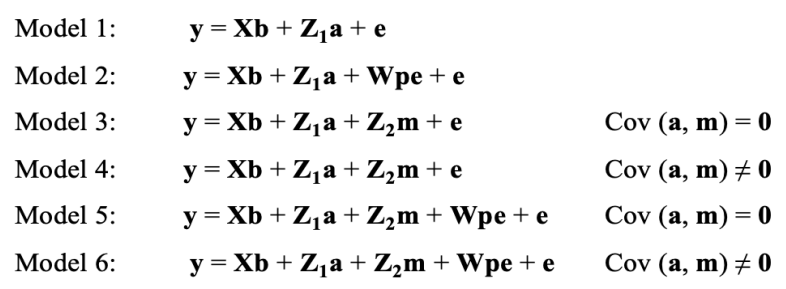

where $\mathbf{y}$ is the continuous random liability of the LSB, $\mathbf{b}, \mathbf{a}, \mathbf{p e}, \mathbf{m}$ and $\mathbf{e}$ are the vectors of fixed, direct genetic, permanent environmental, maternal genetic and residual effects, respectively. Also, $\mathbf{X}, \mathbf{Z 1}, \mathbf{Z 2}$ and $\mathbf{W}$ are the design matrices for fixed, direct genetic, maternal and permanent environmental effects, respectively. It was assumed that residual effects have an independent normal distribution with zero mean and $\sigma_{\circ}^{2}$ variance.

\section{Univariate threshold models}

In the univariate analysis, LSB for each parity was analysed separately. Therefore, the following models were fitted on LSB in each parity:

$\begin{array}{lll}\text { Model 7: } & \mathbf{y}=\mathbf{X b}+\mathbf{Z}_{1} \mathbf{a}+\mathbf{e} & \\ \text { Model 8: } & \mathbf{y}=\mathbf{X b}+\mathbf{Z}_{1} \mathbf{a}+\mathbf{Z}_{2} \mathbf{m}+\mathbf{e} & \operatorname{Cov}(\mathbf{a}, \mathbf{m})=\mathbf{0} \\ \text { Model 9: } & \mathbf{y}=\mathbf{X b}+\mathbf{Z}_{1} \mathbf{a}+\mathbf{Z}_{\mathbf{2}} \mathbf{m}+\mathbf{e} & \operatorname{Cov}(\mathbf{a}, \mathbf{m}) \neq \mathbf{0}\end{array}$

\section{Bivariate threshold models}

In the bivariate analysis, for estimating the genetic correlation between LSB in different parities, three bivariate models were fitted, as follows:

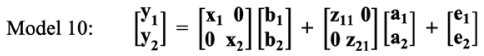

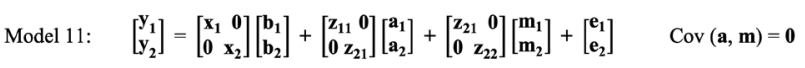

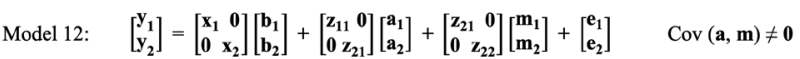

\section{Bayesian estimation and priors}

A uniform prior distribution was assumed for fixed effects. Normal prior distributions $(\mathrm{N})$ were applied to the additive, maternal and permanent environmental effects as:

$\mathbf{a}\left|\mathbf{A}, \sigma_{\mathrm{a}}^{2} \sim \mathrm{N}\left(\mathbf{0}, \mathbf{A} \sigma_{\mathrm{a}}^{2}\right), \mathbf{m}\right| \sigma_{\mathrm{m}}^{2} \sim \mathrm{N}\left(\mathbf{0}, \mathbf{M} \sigma_{\mathrm{m}}^{2}\right), \mathbf{p e} \mid \sigma_{\mathrm{pe}}^{2} \sim \mathrm{N}\left(\mathbf{0}, \mathbf{I} \sigma_{\mathrm{pe}}^{2}\right)$, where $\mathbf{A}, \mathbf{M}$, and $\mathbf{I}$ were the numerator additive genetic, maternal genetic relationship, and the 
identity matrices, respectively. Inverted chisquare distribution was assumed for variance components of additive, maternal, permanent environmental, and residual effects as:

$\sigma_{\mathrm{a}}^{2} \sim \mathbf{X}^{-2},\left(\sigma_{\mathrm{an}_{\mathrm{n}}}^{2}, 5\right), \sigma_{\mathrm{m}}^{2} \sim \mathbf{X}^{-2}\left(\sigma_{\mathrm{m}_{\mathrm{n}}}^{2}, 5\right), \sigma_{\mathrm{pe}}^{2} \sim \mathbf{X}^{-2}\left(\sigma_{\mathrm{pe}_{\mathrm{n}}}^{2}, 5\right), \sigma_{\mathrm{e}}^{2} \sim \mathbf{X}^{-2}\left(\sigma_{\mathrm{e}_{n}}^{2}, 5\right)$, where subscript zero denotes the prior variances. $\sigma_{\mathrm{a}}^{2}, \sigma_{\mathrm{m}}^{2}, \sigma_{\mathrm{pc}}^{2}$ and $\sigma_{\mathrm{e}}^{2}$ were set to $\frac{1}{4}$ of the total variance. For bivariate analysis, bivariate normal prior distributions were used for the additive genetic effect as:

a1, a2 $|A, G \sim N(0, A \otimes G), m 1, m 2| A, M \sim N(0, M \otimes G)$,

where $\otimes$ was the Kronecker product and $G$ and $\mathrm{M}$ were the additive and maternal genetic (co) variance matrices, respectively. Inverted Wishart distributions (IW) were assumed for the (co) variance components as:

$$
\mathbf{G} \sim \mathbf{I W}\left(\mathbf{G}_{\mathbf{0}}, \mathbf{6}\right), \mathbf{M} \sim \mathbf{I W}\left(\mathbf{M}_{0}, \mathbf{6}\right), \mathbf{R} \sim \mathbf{I W}\left(\mathbf{R}_{0}, \mathbf{6}\right) .
$$

Bayesian estimation of variance components and genetic parameters in different threshold models were conducted using Gibbs sampling implemented in THRGIBBS1F90 from the Blupf90 program.

POSTGIBBSF90 was applied to calculate posterior means and $95 \%$ of the highest posterior density region (HPD 95\%). The model compared with different fitted models to select the most appropriate model using the deviance information criterion (DIC) calculated as: $C=2 \times \overline{D(\theta)}-D(\bar{\theta})$, where $\overline{D(\theta)}$ and $D(\bar{\theta})$ are the posterior expectation of log-likelihood and log-likelihood evaluated at the posterior mean of the parameters, respectively. The model with the lowest DIC was considered the best model. In the end, for relevant modelling scenarios, more parameters were computed as well. Total heritability $\left(\mathrm{h}_{\mathrm{t}}^{2}\right)$ was computed as: $\mathrm{h}_{\mathrm{i}}^{2}=\frac{\left(\sigma_{a}^{2}+0.5 \sigma_{m}^{2}+1.5 \sigma_{\mathrm{am}}\right)}{\sigma_{\mathrm{b}}^{2}}$,were $\sigma_{\mathrm{am}}$ Was covariance matrix between additive and maternal effects. Total maternal effect $\left(t_{M}\right)$ was defined as $t_{M}=\frac{1}{4} h^{2}+c^{2}$. Additive coefficient of variation (CVA) was computed as: CVA $=100 *\left(\frac{\sqrt{x}}{x}\right)$. where $\bar{x}$ was the mean number of samples (x) and $\sigma_{A}^{2}$ was additive genetic variance(Ghafouri-Kesbi et al., 2016).

Rev Colomb Cienc Pecu 2022; 35(3, Jul-Sep):125-140 https://doi.org/10.17533/udea.rccp.v35n3a05

\section{Results}

Descriptive statistics of LSB in Makouie sheep are shown in Table 3. The number of records in parity 1 was approximately twice the observations in parity 2 (4,997 vs. 2,219). The total mean ( \pm standard error) and coefficient of variation $(\mathrm{CV})$ of the trait were $1.084 \pm 0.278$ and $26.65 \%, 1.087 \pm 0.282$ and $25.94 \%$ for parities 1 and 2 , respectively. Herd and lambing year had significant effects $(\mathrm{p}<0.05)$ on LSB in this study. The current results showed 0 to $25 \%$ inbreeding rate in the Makouie sheep breed. The number of records in each analysis are shown in Table 3.

Table 3. LSB parameters and number of records in Makouie sheep breed used for the Bayesian analyses.

\begin{tabular}{ccccccc}
\hline Parity & Singles & Twins & Records & Mean & SD & CV\% \\
\hline Parity 1 & 4,997 & 461 & 5,458 & 1.084 & 0.278 & 25.65 \\
Parity 2 & 2,219 & 214 & 2,443 & 1.087 & 0.282 & 25.94 \\
Overall & 7,216 & 675 & 7,901 & 1.088 & 0.283 & 26.01 \\
\hline
\end{tabular}

Estimates of repeated measures threshold models

The mean estimates of MPDs of genetic parameters for LSB obtained from repeated models, standard errors and HPD 95\% interval for the best model (Model 5, shown bold-faced) are provided in Table 4. When maternal effects were considered in the model, additive genetic variance and direct heritability decreased. The direct heritability for LSB ranged from 0.0090 (Model 4) to 0.0380 (Model 1). The additive coefficient of variation CVA was also significantly different among the models and estimated lower in complex models (2.4320 and 2.9065, in Models 4 and 6, respectively) compared to the model with the lowest number of random effects (4.8641; in Model 1).

The animal-dependent permanent environmental variance was estimated as 0.001 . The heritability of LSB in Makouie sheep ranged from 0.01 to 0.03 . The models adopting covariance between additive and maternal effects resulted in lower estimations of total heritability. Figure 1 shows the MPDs of direct and maternal heritabilities (\%) in repeated measurement analysis (the best model). 
Table 4. Mean estimates of marginal posterior distributions of LSB genetic parameters by repeated analysis.

\begin{tabular}{|c|c|c|c|c|c|c|}
\hline Parameters & M1 (SE) & M2 (SE) & M3 (SE) & M4 (SE) & $\begin{array}{c}\text { M5 (SE) } \\
\text { (Confidence } \\
\text { Interval for the } \\
\text { best model) }\end{array}$ & M6 (SE) \\
\hline$\sigma_{\mathrm{a}}^{2}$ & $0.0028(0.001)$ & $0.002(0.001)$ & $0.0014(0.0009)$ & $0.0007(0.0007)$ & $\begin{array}{l}0.0012(0.0008) \\
(0.001 \text { to } 0.003)\end{array}$ & $0.001(0.001)$ \\
\hline$\sigma_{\mathrm{m}}^{2}$ & --- & --- & $0.0025(0.0009)$ & $0.0025(0.0016)$ & $\begin{array}{l}0.0022(0.0015) \\
(0.001 \text { to } 0.005)\end{array}$ & $0.003(0.001)$ \\
\hline$\sigma_{\mathrm{c}}^{2}$ & --- & $0.001(0.0008)$ & --- & --- & $\begin{array}{l}0.0010(0.0008) \\
(0.001 \text { to } 0.003)\end{array}$ & $0.001(0.0009)$ \\
\hline$\sigma_{\mathrm{e}}^{2}$ & $0.0713(0.001)$ & $0.071(0.001)$ & $0.0703(0.001)$ & $0.0708(0.0015)$ & $\begin{array}{l}0.0698(0.0015) \\
(0.067 \text { to } 0.073)\end{array}$ & $0.070(0.001)$ \\
\hline$\sigma_{\mathrm{p}}^{2}$ & $0.0741(0.001)$ & $0.074(0.001)$ & $0.0742(0.001)$ & $0.0740(0.0015)$ & $\begin{array}{l}0.0742(0.0012) \\
(0.068 \text { to } 0.083)\end{array}$ & $0.075(0.001)$ \\
\hline$h_{a}^{2}$ & $0.0380(0.014)$ & $0.0270(0.015)$ & $0.0182(0.012)$ & $0.0090(0.0098)$ & $\begin{array}{c}0.0162(0.010) \\
(0.001 \text { to } 0.034)\end{array}$ & $0.019(0.013)$ \\
\hline $\mathrm{h}_{\mathrm{m}}^{2}$ & --- & --- & $0.0343(0.012)$ & $0.0339(0.0212)$ & $\begin{array}{c}0.0294(0.014) \\
(0.006 \text { to } 0.043)\end{array}$ & $0.037(0.019)$ \\
\hline$c^{2}$ & --- & $0.0150(0.012)$ & --- & --- & $\begin{array}{c}0.0136(0.011) \\
(0.001 \text { to } 0.034)\end{array}$ & $0.015(0.012)$ \\
\hline $\mathrm{r}$ & --- & $0.0420(0.017)$ & --- & --- & --- & --- \\
\hline $\mathrm{h}_{\mathrm{t}}^{2}$ & --- & --- & 0.0353 & 0.0289 & 0.0310 & 0.0142 \\
\hline $\mathrm{t}_{\mathrm{M}}$ & 0.0007 & 0.02175 & 0.0003 & 0.0001 & 0.0177 & 0.0198 \\
\hline $\mathrm{V}_{\mathrm{a}} / \mathrm{V}_{\mathrm{e}}$ & 0.0390 & 0.0280 & 0.0200 & 0.0100 & 0.0170 & 0.0140 \\
\hline $\mathrm{ACV}$ & 4.8641 & 4.1100 & 3.4393 & 2.4320 & 3.1840 & 2.9065 \\
\hline DIC & 1895 & 1897 & 1891 & 1894 & 1890 & 1892 \\
\hline
\end{tabular}

M: Model, SE: Standard errors, $\sigma_{\mathrm{a}}^{2}$ : Direct genetic variance, $\sigma_{\mathrm{m}}^{2}$ : Maternal genetic variance, $\sigma_{\mathrm{c}}^{2}:$ Permanent environmental variance, $\sigma_{\mathrm{e}}^{2}$ : Residual variance, $\sigma_{\mathrm{p}}^{2}:$ Phenotypic variance, $\mathrm{h}_{\mathrm{a}}^{2}:$ Direct heritability, $\mathrm{h}_{\mathrm{m}}^{2}:$ Maternal heritability, $\mathrm{c}^{2}:$ Ratio of permanent environmental variance to phenotypic variance, $r$ : Repeatability, $h_{t}^{2}:$ Total heritability, $t_{M}$ : Total maternal effect, $V_{a}:$ additive variance, $\mathrm{V}_{\mathrm{e}}$ : error variance, ACV: Additive Coefficient of Variation, DIC: Deviance Information Criterion.

\section{Estimates of univariate analysis}

The additive genetic variance and direct heritability estimated by Models 7 and 8 were higher in parity 1 compared to those of parity 2. But the estimates obtained by Model 9 were higher in parity 2. The highest estimate of CVA was observed in Model 9 and this pattern was similar in both parities. Also, the highest estimate of additive genetic variance, maternal genetic variance direct heritability and maternal heritability $(0.014,0.024$, 0.151 and 0.259 , respectively, in model 9) were observed in parity 2 .
The means of posterior distributions (MPDs) of direct and maternal heritabilities in parities 1 and 2 were plotted for the best model (Figure 2).

The MPDs of direct heritabilities for parities 1 and 2 were very similar and were skewed in these parities. The highest ACV was estimated in Model 9 in each parity (4.11, 5.03 and 9.19 for Models 7, 8 and 9, respectively), and was maximum in parity 2. This trend was also observed for total maternal effect. The maximum estimate for total heritability was obtained for Model 8 in parity $2(0.249)$. 


\section{Estimates of the bivariate model}

Means of MPDs, standard errors and HPD $(95 \%)$ interval of parameters for the best fitted model in bivariate analyses of LSB are summarized in Table 6. Minimum (0.002) and maximum (0.010) estimates of genetic variance in parity 1 were obtained by Model 11 and Model 12, respectively. For maternal genetic variance, Model 12 had a higher estimate in parity $1(0.010)$ than parity $2(0.008)$.

In Model 11, an increasing trend for genetic variance was observed from parity 1 (0.004) to parity $2(0.013)$. The estimates of direct heritabilities in parity 1 ranged from 0.030 (Model 10) to 0.118 (Model 12). On the other hand, maximum (0.220 in Model 11) and minimum ( 0.050 in Model 10) estimates of direct heritabilities were observed in parity 2 . Conversely, the opposite trend was observed for maternal heritabilities in the present study (Model 11: 0.180 to 0.170; Model 12: 0.117 to 0.103 from parity 1 to 2 ). The largest estimate of total heritabilities for LSB was obtained using Model 11 for the first two parities.
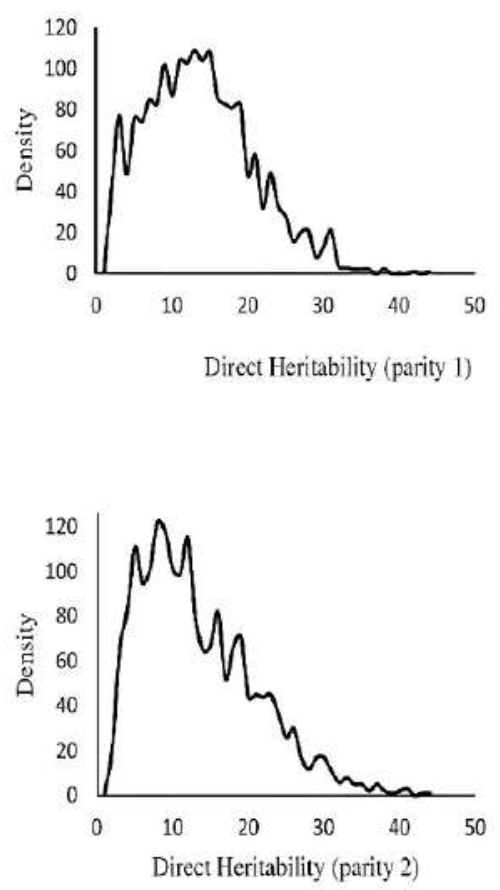
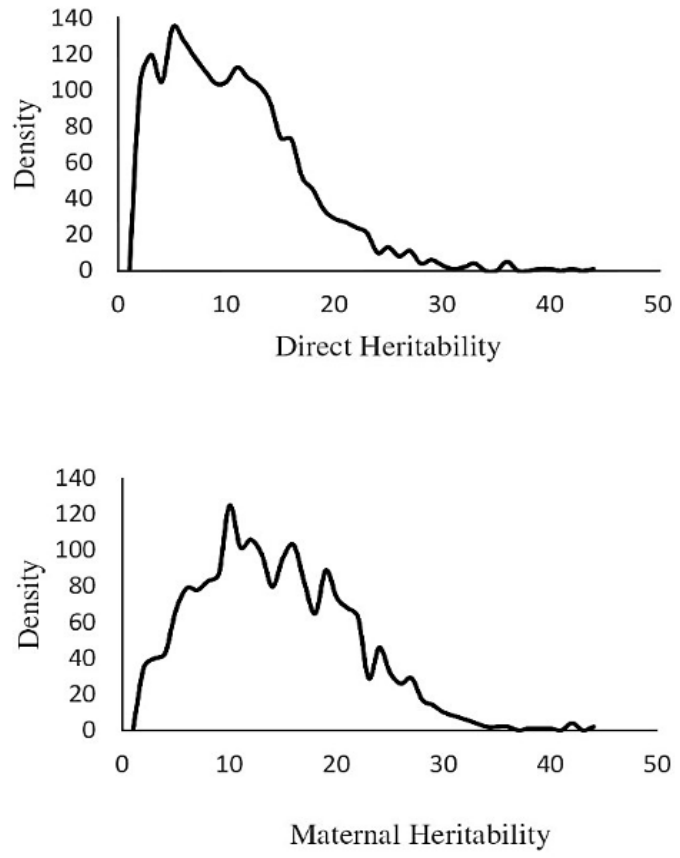

Figure 1. Marginal posterior distributions of LSB in repeated measurement analysis (Model 5).
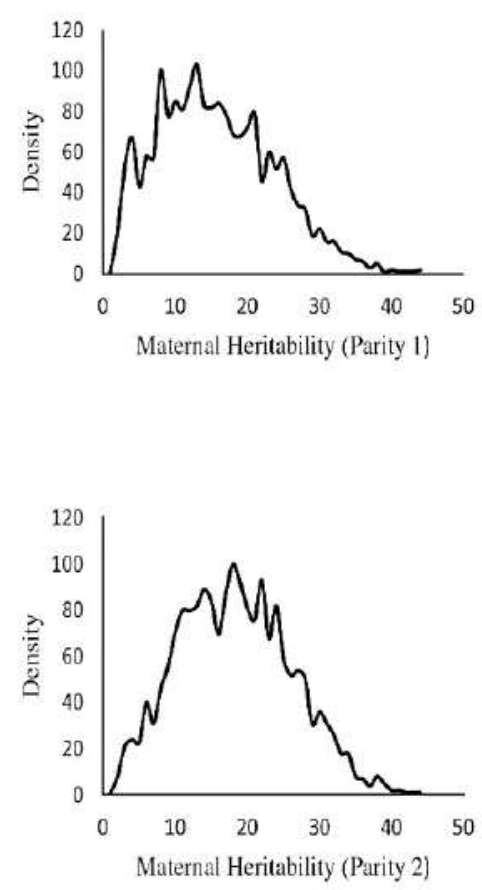

Figure 2. Marginal posterior distributions of LSB in univariate analysis (Model 9). 
Table 5. Means of marginal posterior distributions of LSB genetic parameters by univariate analysis.

\begin{tabular}{|c|c|c|c|c|c|c|c|c|c|c|c|c|}
\hline Parity & Model & $\sigma_{\mathrm{a}}^{2}$ & $\sigma_{\mathrm{m}}^{2}$ & $\sigma_{\mathrm{e}}^{2}$ & $\sigma_{\mathrm{p}}^{2}$ & $\mathrm{~h}_{\mathrm{a}}^{2}$ & $\mathrm{~h}_{\mathrm{t}}^{2}$ & $\mathrm{~h}_{\mathrm{m}}^{2}$ & $\mathrm{t}_{\mathrm{M}}$ & $\mathrm{V}_{\mathrm{a}} / \mathrm{V}_{\mathrm{e}}$ & $\mathrm{ACV}$ & DIC \\
\hline \multirow[t]{3}{*}{ Parity 1} & M7 (SE) & $0.007(0.002)$ & --- & $0.066(0.003)$ & $0.073(0.001)$ & $0.099(0.038)$ & --- & --- & 0.02475 & 0.106 & 7.68 & 1208 \\
\hline & M8 (SE) & $0.005(0.002)$ & $0.005(0.002)$ & $0.064(0.002)$ & $0.073(0.001)$ & $0.067(0.037)$ & 0.1002 & $0.065(0.029)$ & 0.01675 & 0.078 & 6.499 & 1188 \\
\hline & $\begin{array}{l}\text { M9 (SE) } \\
\text { (Confidence } \\
\text { Interval for the } \\
\text { best model) }\end{array}$ & $\begin{array}{c}0.009(0.005) \\
(0.001 \text { to } 0.02)\end{array}$ & $\begin{array}{c}0.007(0.003) \\
(0.001 \text { to } 0.014)\end{array}$ & $\begin{array}{c}0.061(0.004) \\
(0.053 \text { to } 0.069)\end{array}$ & $\begin{array}{c}0.077(0.003) \\
(0.055 \text { to } 0.102)\end{array}$ & $\begin{array}{c}0.122(0.064) \\
(0.019 \text { to } 0.193)\end{array}$ & 0.0911 & $\begin{array}{c}0.088(0.045) \\
(0.012 \text { to } 0.134)\end{array}$ & 0.0305 & 0.147 & 8.71 & 1135 \\
\hline \multirow[t]{3}{*}{ Parity 2} & M7 (SE) & $0.003(0.003)$ & --- & $0.073(0.003)$ & $0.076(0.002)$ & $0.044(0.041)$ & --- & --- & 0.011 & 0.041 & 5.03 & 675 \\
\hline & M8 (SE) & $0.004(0.003)$ & $0.008(0.003)$ & $0.064(0.004)$ & $0.076(0.002)$ & $0.056(0.041)$ & 0.1067 & $0.101(0.051)$ & 0.014 & 0.062 & 5.81 & 636 \\
\hline & $\begin{array}{l}\text { M9 (SE) } \\
\text { (Confidence } \\
\text { Interval for the } \\
\text { best model) }\end{array}$ & $\begin{array}{c}0.014(0.009) \\
(0.002 \text { to } 0.03)\end{array}$ & $\begin{array}{c}0.024(0.009) \\
(0.007 \text { to } 0.042)\end{array}$ & $\begin{array}{c}0.054(0.008) \\
(0.039 \text { to } 0.07)\end{array}$ & $\begin{array}{c}0.092(0.008) \\
(0.028 \text { to } 0.141)\end{array}$ & $\begin{array}{c}0.151(0.082) \\
(0.042 \text { to } 0.211)\end{array}$ & 0.0202 & $\begin{array}{c}0.259(0.083) \\
(0.145 \text { to } 0.297)\end{array}$ & 0.03775 & 0.259 & 10.88 & 483 \\
\hline
\end{tabular}

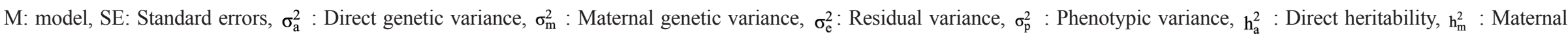
heritability, $\mathrm{h}_{\mathrm{t}}^{2}$ : Total heritability, $\mathrm{t}_{\mathrm{M}}$ : Total maternal effect, $\mathrm{V}_{\mathrm{a}}$ : additive variance, $\mathrm{V}_{\mathrm{e}}$ : error variance, ACV: Additive Coefficient of Variation, DIC: Deviance Information Criterion. 
Table 6. Means of marginal posterior distributions of LSB genetic parameters in bivariate analysis.

\begin{tabular}{|c|c|c|c|c|c|c|c|c|c|c|c|c|}
\hline Parity & Model & $\sigma_{\mathrm{a}}^{2}$ & $\sigma_{\mathrm{m}}^{2}$ & $\sigma_{\mathrm{e}}^{2}$ & $\sigma_{\mathrm{p}}^{2}$ & $\mathrm{~h}_{\mathrm{a}}^{2}$ & $\mathrm{~h}_{\mathrm{t}}^{2}$ & $\mathrm{~h}_{\mathrm{m}}^{2}$ & $t_{M}$ & $\mathrm{~V}_{\mathrm{a}} / \mathrm{V}_{\mathrm{e}}$ & $\mathrm{ACV}$ & DIC \\
\hline \multirow[t]{3}{*}{ Parity 1} & $\begin{array}{l}\text { M10 (SE) } \\
\text { (Confidence } \\
\text { Interval } \\
\text { for the best } \\
\text { model) }\end{array}$ & $\begin{array}{c}0.002 \\
(0.0013) \\
(0.001 \text { to } \\
0.007)\end{array}$ & --- & $\begin{array}{c}0.07 \\
(0.002) \\
(0.66 \text { to } \\
0.076)\end{array}$ & $\begin{array}{c}0.07 \\
(0.001) \\
(0.066 \text { to } \\
0.082)\end{array}$ & $\begin{array}{c}0.03 \\
(0.027) \\
(0.003 \text { to } \\
0.075)\end{array}$ & --- & --- & 0.0075 & 0.028 & 4.11 & -1810453 \\
\hline & M11 (SE) & $\begin{array}{c}0.003 \\
(0.0012)\end{array}$ & $\begin{array}{c}0.004 \\
(0.0013)\end{array}$ & $\begin{array}{c}0.06 \\
(0.002)\end{array}$ & $\begin{array}{c}0.07 \\
(0.001)\end{array}$ & $\begin{array}{c}0.04 \\
(0.021)\end{array}$ & 0.0825 & $\begin{array}{c}0.18 \\
(0.018)\end{array}$ & 0.01 & 0.05 & 5.03 & -888836 \\
\hline & M12 (SE) & $\begin{array}{c}0.010 \\
(0.003)\end{array}$ & $\begin{array}{c}0.010 \\
(0.003)\end{array}$ & $\begin{array}{c}0.062 \\
(0.003)\end{array}$ & $\begin{array}{c}0.081 \\
(0.004)\end{array}$ & $\begin{array}{c}0.118 \\
(0.035)\end{array}$ & 0.0368 & $\begin{array}{c}0.117 \\
(0.093)\end{array}$ & 0.0295 & 0.161 & 9.19 & - 944623 \\
\hline \multirow[t]{3}{*}{ Parity 2} & $\begin{array}{l}\text { M10 (SE) } \\
\text { (Confidence } \\
\text { Interval } \\
\text { for the best } \\
\text { model) }\end{array}$ & $\begin{array}{c}0.010 \\
(0.006) \\
(0.004 \text { to } \\
0.03)\end{array}$ & --- & $\begin{array}{c}0.05 \\
(0.006) \\
(0.045 \text { to } \\
0.071)\end{array}$ & $\begin{array}{c}0.07 \\
(0.002) \\
(0.049 \text { to } \\
0.1)\end{array}$ & $\begin{array}{c}0.22 \\
(0.041) \\
(0.077 \text { to } \\
0.294)\end{array}$ & --- & --- & 0.055 & 0.2 & 9.19 & --- \\
\hline & M11 (SE) & $\begin{array}{c}0.013 \\
(0.006)\end{array}$ & $\begin{array}{c}0.013 \\
(0.003)\end{array}$ & $\begin{array}{c}0.05 \\
(0.006)\end{array}$ & $\begin{array}{c}0.07 \\
(0.002)\end{array}$ & $\begin{array}{c}0.05 \\
(0.081)\end{array}$ & 0.2490 & $\begin{array}{c}0.17 \\
(0.049)\end{array}$ & 0.0125 & 0.26 & 10.47 & ---- \\
\hline & M12 (SE) & $\begin{array}{c}0.014 \\
(0.007)\end{array}$ & $\begin{array}{c}0.008 \\
(0.003)\end{array}$ & $\begin{array}{c}0.060 \\
(0.006)\end{array}$ & $\begin{array}{c}0.083 \\
(0.009)\end{array}$ & $\begin{array}{c}0.175 \\
(0.072)\end{array}$ & 0.1091 & $\begin{array}{c}0.103 \\
(0.048)\end{array}$ & 0.0437 & 0.233 & 10.87 & --- \\
\hline
\end{tabular}

M: model, SE: Standard errors, $\sigma_{\mathrm{a}}^{2}:$ Direct genetic variance, $\sigma_{\mathrm{m}}^{2}:$ Maternal genetic variance, $\sigma_{\mathrm{e}}^{2}:$ Residual variance, $\sigma_{\mathrm{p}}^{2}:$ Phenotypic variance, $\mathrm{h}_{\mathrm{a}}^{2}:$ Direct heritability, $\mathrm{h}_{\mathrm{m}}^{2}:$ Maternal heritability, $\mathrm{h}_{\mathrm{t}}^{2}$ : Total heritability, $\mathrm{t}_{\mathrm{M}}$ : Total maternal effect, $\mathrm{V}_{\mathrm{a}}$ : additive variance, $\mathrm{V}_{\mathrm{e}}$ : error variance, ACV: Additive Coefficient of Variation, DIC: Deviance Information Criterion. 

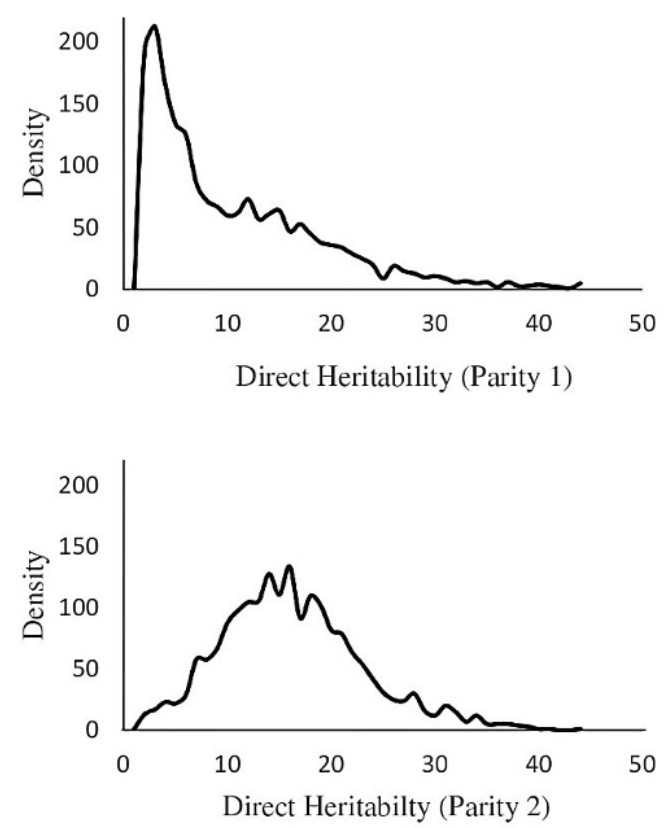

Figure 3. Marginal posterior distributions of LSB rate in bivariate analysis (Model 10).

\section{Correlations between LSB at different parities}

The estimates of phenotypic, direct genetic, maternal genetic, and residual correlations for LSB in the first two parities of Makouie sheep are shown in Table 7.

\section{Discussion}

The number of records in parity 2 was less than parity 1 , which could be due to culling or mortality of some ewes after the first lambing. The mean of LSB in parity 1 (1.084) and parity
2 (1.087) showed a relatively flat trend that was consistent with the means reported by Bunter et al. (2013), suggesting that with increasing age, the mean of LSB increases from 1.40 (yearling) and 1.62 ( 2 years of age) to 1.74 ( $>2$ years of age). Two breeds (maternal-cross ewes and merino ewes) were classified using their reproductive performance as a yearling (under 1.5 years of age), hogget (from 1.5 to 2.5 years of age) and adult (upper 2.5 years of age) groups (Newton et $a l ., 2014)$. There is a tendency to improve ewe productivity with age (Ekiz et al., 2005) and it generally reaches a maximum level between four and seven years of age in ewes (Sodiq et al., 2011), but this was not confirmed in this study. However, the differences among parities were negligible (1.084 vs. 1.087 for parity 1 and 2 , respectively). This was probably due to the low number of twins in the first two parities of Makouie sheep (twins in parity 1 and 2 were 9.22 and $8.79 \%$ of all records, respectively). These results were similar to the mean number of LSB reported in Baluchi sheep (1.10 to 1.12 in parity 1 to parity 4), but showed discrepancy with another report (Dominik et al., 2016; Yazdi et al., 1999). Our results were in agreement with the estimated mean numbers of LSB (1.75 in the first parity and 1.88 in the second parity) in Mule ewes (Mekkawy et al., 2010). Since the frequency of twins was low, this could have consequently resulted in a small variance. An average CV of LSB (36\%) indicated the low phenotypic variation of this trait (Fogarty et al., 1995).

Table 7. Estimates of correlations between LSB at different parities.

\begin{tabular}{lcc}
\hline & Parity 1 & Parity 2 \\
\hline Parity 1 & Maternal genetic and phenotypic correlations & $0.2575 \mathrm{a}(0.054)$ \\
Parity 2 & 1 & 1 \\
& $0.0708 \mathrm{a}(0.004)$ & $0.1243 \mathrm{a}(0.021)$ \\
Parity 1 & Direct genetic and environmental correlation & 1 \\
Parity 2 & 1 & $0.0663 \mathrm{a}(0.002)$ \\
\hline
\end{tabular}

Off-diagonal: maternal genetic correlation (above) and phenotypic correlation (below), Off-diagonal: direct genetic correlation (above) and residual correlation (below). aSignificant at $\mathrm{p}<0.05$. 
The significant effect of lambing year can be partially described by the variation in the climate conditions and impact of pasture on sheep feeding as well as different management and breeding conditions of ewes in different years (Yavarifard et al., 2015). The results showed that direct heritability estimates in all models were very low in the Makouei breed and ranged from 0.009 (Model 4) to 0.038 (Model 1). These results were in accordance with findings in Kermani sheep (0.01), Shall sheep (0.02), Zandi sheep (0.11), D'man ewes (0.1) and Lori sheep (0.175) (Mokhatri et al., 2009; Posht-e-Masari et al., 2013; Mohammadi et al., 2012; Boujenane et al., 2013; Mohammadi et al., 2015); however, a very low heritability for LSB (0.00) was estimated using a similar method in Guilan sheep (Eteqadi et al., 2017), and a nearly higher estimate (0.12) was reported using the same method in Australian fine-wool merino sheep (Mekkawy et al., 2010). The results showed that maternal variances were relatively high across entire estimated variance components, indicating higher effects of these components on LSB in Makouie sheep. The ACVs (Fogarti et al., 1995) over different models were different and the highest values for ACV were estimated for Models 1 and 2 (4.86 and 4.11, respectively), indicating a possible potential to genetically improve LSB in this parity. Interestingly, the largest estimate of SE was also observed in parity 2 for Model 9. This may be due to the lower number of records in parity 2 than in parity 1 . By increasing the age of ewes and then parities, direct genetic variances increased in all modelling scenarios, which could be due to the lower direct heritability of reproductive traits and greater proportional influence of environmental effects than others. The heritability of LSB in Arabi sheep was estimated as 0.05 , which was nearly in accordance with the present results in parity 1 (0.06 for Model 8) and parity 2 (0.044 and 0.056 for Models 7 and 8, respectively) (Roshanfekr et al., 2015). Interestingly, an increasing trend was observed for total heritability with increasing parity. A direct heritability of 0.03 was reported for LSB in Makouie sheep (Jafari et al., 2014), which is in accordance with current results obtained by bivariate analysis in parity 1 and 2. The direct heritabilities for LSB in the first three parities in Baluchi ewes using Bayesian bivariate analysis were 0.34 to 0.43 (Yazdi et al., 1999). The multivariate analysis was used and direct heritabilities were estimated as 0.52 to 0.57 for LSB in the first to fifth parities of Hungarian Merino sheep (Nagi et al., 1999). The Bayesian bivariate analysis estimated direct heritabilities from 0.12 to 0.18 for LSB in Mule ewes (Yavarifard et al., 2015). The MPDs for maternal heritabilities were different and, except for parity 2, the other parities had different trends that did not follow a Gaussian distribution. The MPDs of maternal heritabilities for LSB in parity 1 were more skewed than in parity 2 , possibly due to the low number of twins at this parity. Moreover, it did not fit a normal distribution. A multi-trait analysis of LSB in five sheep breeds showed that estimated heritabilities had an ascending trend in parity 1 through parity 3 (Hagger et al., 2002).

In Model 9, direct and maternal heritabilities increased as the parity number increased. This is completely in agreement with another study that categorized reproductive performance of ewes based on their age (yearling, 2 years of age, and upper ages), and that heritability of LSB increased as age increased $(0.05,0.10$ and 0.11 for yearling, 2 and $2+$ ages, respectively) (Newton et al., 2014). However, the present results contrasted to another study where estimated heritability had a decreasing trend in cross-maternal ewes with increasing age (Ekiz et al., 2005). On the other hand, in two other models, the estimates of parameters in parity 2 showed a descending trend. The highest estimate of maternal variance for parity $2(0.024)$ was obtained in the last model. This could be due to the maturity of ewes in parity 2 when they have become post-pubertal. Young mothers (2 to 3 years old) give birth to lighter lambs than sheep in middle age ( 4 to 5 years old) (Milan et al., 2011). In parity 2 , the genetic variance was greater than in parity 1 . Trends of estimated direct heritabilities from parity 1 to parity 2 in each model increased (Table 6) (Roshanfekr 
et al., 2015; Yazdi et al., 1999; Hagger et al., 2002). The production and reproductive traits in four sheep breeds (Danish Texel, Shropshire, Oxford Down and Suffolk) were studied to find that direct and maternal heritabilities of LSB in bivariate analyses were increased with increasing parities and direct heritabilities for the Suffolk breed and other breeds were reported to be 0.04 and 0.06 , respectively (Maxa et al., 2005). This trend showed that LSB was affected by different genetic and environmental factors in each parity. Ascending trends were obtained for total heritabilities, total maternal effects and ACVs from parity 1 to 2 . It seems that high additive genetic variances of LSB in parity 2 would result in high ACV values. Model 10 was selected as the best one in the bivariate analysis of LSB in Makouie sheep based on the DIC values. Figure 3 shows the MPDs of direct heritability for LSB in bivariate analysis. This indicates the similarity of environmental effects affecting LSB in different parities of Makouie sheep. It has been suggested that when the genetic correlation between repeated observations at different times is $>0.80$, there is no need to treat repeated observations as different traits because selection response will not significantly improve by this strategy (Yavarifard et al., 2015). Therefore, considering LSB at different parities as separate traits would be an acceptable strategy because twin lambing rate and heritability of LSB was very low as well as we found LSB's genetic correlation between two parities was very low (0.12). In this way, the maternal genetic correlation of LSB between two parities was also positive $(0.26)$. High genetic correlations have been reported between parities or age groups for LSB in other studies, e.g., 0.928 to 0.999 between the first three parities (Hagger et al., 2002), 0.85 in different age groups (yearling, 2 and $>2$ ages) (Newton et al., 2014), 0.7 between parities 1 and 2 in Mule ewes (Yavarifard et al., 2015), and 0.8 between the first two parities in Hungarian Merino sheep (Nagi et al., 1999) using multivariate analysis. Overall, a positive correlation between LSB in different parities was observed. The factors that affect LSB in sheep are known: follicular activity, initiation of ovulation, ewe condition during mating, various gene activities including the activity of GDF9, Booroola, uterine environment, sheep maturity and age, effects of disease and abortion, feed availability and feeding, lamb birth weight, lamb thermogenesis, the effect of parasites, etc. Therefore, LSB is the net outcome of various factors that are typically variable, although they may not be easily controlled or individually measured. Overall, LSB could be considered a foundation for further analysis of the various factors related to lamb survival and lambing performance. The permanent environmental estimation of LSB in Makouie sheep was 0.015, indicating a considerable influence of environmental effects on LSB in Makouie sheep when compared with its heritability (0.027). Direct heritability of number of lambs born in Makouie sheep was reported as 0.03 (Jafari et al., 2014), which agreed with the present results (Model 1). Direct heritability and the ratio of permanent environmental effect to LSB in Rambuillet ewes were estimated as 0.09 and 0.05, respectively (Hanford et al., 2005). Direct heritability of number of lambs born per lambing was reported as 0.1 in Lori Bakhtiari sheep (Vatankhah et al., 2008). In the context of repeatability analysis, Model 5 was fitted on data with the best DIC criterion. Estimates of direct heritability, direct genetic and permanent environmental effects in all analyses and models compared well to findings of other studies and were very low, mainly due to the typical strong influences of environmental factors on LSB and low occurrence of twins in Makouie sheep.

In conclusion, the estimated means of MPDs of genetic parameters of LSB in Makouie sheep in conventional repeated models, univariate and bivariate models were obtained. Comparing different repeated models, the model with additive genetic, maternal and permanent environmental effects was the best. Under univariate analysis, estimated parameters of the best model (fitting additive genetic and maternal effects) increased with increasing parity, while a decreasing trend was obtained for other models. The results showed that the estimated variance components were very different among parities and depend on 
the model. Differences in estimated parameters over parities suggest that different factors influence LSB over time in Makouie sheep. In bivariate analysis, an increasing trend for genetic parameters over parities was obtained (based on the best model). Direct genetic and maternal effects have an important effect on LSB in Makouie sheep. We observed an ascending trend for direct heritabilities over parities.

\section{Declarations}

\section{Acknowledgment}

Sincere thanks are expressed to Shoja Jafari, head of the Makouie sheep breeding center in Makou, for his appreciable help in the implementation of this work. Also, the authors thank Rayan-Zist-Fanavari-Pars-Avid Co. for its support.

\section{Conflicts of interest}

The authors declare they have no conflicts of interest with regard to the work presented in this report.

\section{Author contributions}

The authors have the same contribution in the current study.

\section{References}

Abdel-AzimGA,BergerPJ.Propertiesofthreshold model predictions. J Anim Sci1999; 77(3): 582-590. https://doi.org/10.2527/1999.773582x

Allison PD. Logistic Regression using SAS Systems: Theory and Applications. Cary, NC, USA: SAS Institute Inc; 2001.

Altarriba J, Varona L, Garcia-cortes LA, Moreno C. Bayesian inference of variance components for twinning LSB in Rasa Aragonesa sheep. Anim Sci J 1998; 76(1): 23-28. https://doi.org/10.2527/1998.76123x

Alves A, Lôbo A, Facó O, Silva L, Lôbo R. Genetic parameters for rank of the Santa Inês sheep in agricultural fairs using Bayesian procedures. Ital J Anim 2016; 15(4): 604-609. https://doi.org/10.1080/1828051X.2016.1248866

Boujenane I, Chikhi A, Sylla M, Ibnelbachyr M. Estimationofgeneticparameters andgenetic gains for reproductive traits and body weight of D'man ewes. Small Rumin Res 2013; 113(1): 40-46. https://doi.org/10.1016/j.smallrumres.2013.02.009

Bunter KL, Brown DJ. Yearling and adult expressions of reproduction in maternal sheep breeds are genetically different traits. In: Proceeding of the 20th Conference of the Association for the Advancement of Animal Breeding and Genetics; Napier, New Zealand; 2013. pp. 82-85.

Casellas J, Caja G, Ferret A, Piedrafita J. Analysis of litter size and days to lambing in the Ripollesa ewe: I. Comparison of models with linear and threshold approaches. J Anim Sci 2007; 85(3): 618-624. https://doi.org/10.2527/jas.2006-365

Ciappesoni G, Goldberg V, Gimeno D. Estimates of genetic parameters for worm resistance, wool and growth traits in Merino sheep of Uruguay. Livest. Sci. 2013; 157(1): 65-74. https://doi.org/10.1016/j.livsci.2013.07.011

De Vries MJ, Van-Der Wajj EH, Van-Arendoc JAM. Estimation of genetic parameters for LSB in sheep: a comparison of repeatability and a bivariate model. Anim Sci 1998; 66: 685-688.

Dominik S, Swan A. Genetic and phenotypic parameters for reproduction, production and bodyweight traits in Australian fine-wool Merino sheep. Anim Prod Sci 2016; 58(2): 207-212. https://doi.org/10.1071/AN15738

Ekiz B, Özcan M, Yilmaz A, Ceyhan A. Estimation of phenotypic and genetic parameters for ewe productivity traits of Turkish merino (karacabey merino) sheep. Turk J Vet Anim Sci 2005; 29(2): 557-564.

Esmailizadeh A, Miraei-Ashtiani SR, Mokhtari MS, Asadi-Fozi M. Growth performance of crossbred lambs and productivity of Kurdi ewes as affected by the sire breed under extensive 
production system. J Agric Sci 2011; 13(5): 701-708.

Eteqadi B, Ghavi Hossein-Zadeh N, Shadparvar A. Genetic analysis of basic and composite reproduction traits in Guilan sheep. Ann. Anim. Sci. 2017; 17(1): 105-116. https://doi.org/10.1515/aoas-2016-0016

Fogarty NM. Genetic parameters for live weight, fat and muscle measurements, wool production and reproduction in sheep: a review. Anim Breed Abstracts 1995; 63(3): 101-143.

Ghafouri-Kesbi F, Notter DR. Sex influence on genetic expressions of early growth in Afshari lambs. Arch Tierzucht 2016; 59(1): 9-17.

Ghavi Hossein-Zadeh N, Ardalan M. Estimation of genetic parameters for body weight traits and litter size of Moghani sheep using a Bayesian approach via Gibbs sampling. J Agric Sci 2010; 148 (3): 363-370. https://doi.org/10.1017/S0021859610000080

Gowane GR, Prince L, Lopes FB, Paswan C, Sharma RC. Genetic and phenotypic parameter estimates of live weight and daily gain traits in Malpura sheep using Bayesian approach. Small Rumin Res 2015; 128: 10-18. https://doi.org/10.1016/j.smallrumres.2015.04.016

Hagger C. Multitrait and repeatability estimates of random effects on litter size in sheep. Anim Sci 2002; 74(2): 209-216. https://doi.org/10.1017/S1357729800052371

Hanford KJ, Van-Vleck LD, Snowder GD. Estimate of genetic parameters and genetic change for reproduction, weight and wool characteristics of Rambuillet sheep. Small Rumin Res 2005; 57: 175-186. https://doi.org/10.1016/j.smallrumres.2004.07.003

Jafari S, Hashemi A, Darvishzadeh R, Manafiazar G. Genetic parameters of live body weight, body measurements, greasy fleece weight, and reproduction traits in Makouie sheep breed. Span J Agric Res 2014; 12(3): 653-663. https://doi.org/10.5424/ sjar/2014123-4564
Jafari S, Hashemi A. Genetic analysis of fleece and post-weaning body weight traits in Makouie sheep. Genet Mol Res 2014; 13(1): 1079-1087. https://doi.org/10.4238/ 2014.February. 20.9

Jafari S, Hashemi A， Manafiazer G, Darvishzadeh R, Razzaghzadeh S et al. Genetic analysis of growth traits in Iranian Makouie sheep breed. Ital J Anim 2012; 11(1): 98-102. https://doi.org/10.4081/ijas.2012.e18

Júnior F, Silva LA, Sarmento J, Santos N, Sena LS et al. Estimate of genetic parameters for carcass traits and visual scores in meat sheep using Bayesian inference via threshold and linear models. Ciência Rural 2017; 47(3): 1-6. https://doi.org/10.1590/0103-8478cr20160174

King R, Brooks SP, Morgan BJ, CoulsonT.Factors influencing Soay sheep survival: A Bayesian analysis. Biometrics 2006; 62(1): 211-220. https://doi.org/10.1111/j.15410420.2005. 00404.x

Latifi M, Mohammadi A, Bohlouli M, Alijani S. Estimation of genetic parameters of litter size in Moghani sheep using threshold model via Bayesian approach. J Liv Sci Tech 2017; 5(1): 59-65. https://doi.org/10.22103/jlst.2017.10533.1199

Maxa J, Norberg E, Berg P, Pedersen J. Genetic parameters for growth traits and LSB in Danish Texel, Shropshire, Oxford Down and Suffolk. Small Rumin Res 2007; 68: 312-317. https://doi.org/10.1016/j.smallrumres.2005.12.001

Mekkawy W, Rohe R, Lewis RM, Davis MH, Bunger L, Simm G, Haresign W. Comparison of repeatability and multiple trait threshold models in sheep using observed and simulated data in Bayesian analyses. J Anim Breed Genet 2010; 127: 261-271. https://doi.org/10.1111/j.1439-0388.2010.00852.x

Milán MJ, Caja G, González-González R, Fernández-Pérez AM, Such X. Structure and performance of Awassi and Assaf dairy sheep farms in northwestern Spain. Int J Dairy Sci 2011; 94(2): 771-784. https://doi.org/10.3168/jds.2010-3520 
Mohammadi K,Abdollahi-ArpanahiR,Amraei F, Mohammadi EM, Rashidi A. Genetic parameter estimates for growth and reproductive traits in Lori sheep. Small Rumin Res 2015; 131: 35-42. https://doi.org/10.1016/j.smallrumres.2015.07.029

Mohammadi H, Moradi-Shahrbabak M, MoradiShahrbabak H, Vatankhah M. Estimation of genetic parameters of reproductive traits in Zandi sheep using linear and threshold models. Czech J Anim Sci 2012; 57(7): 382-388. https://doi.org/10.17221/6274-CJAS

Mohammadi H, Moradi-Shahrbabak M, Moradi-Shahrbabak H. Genetic analysis of ewe productivity traits in Makouei sheep. Small Rumin. Res 2012; 107(2): 105-110. https://doi.org/10.1016/j.smallrumres.2012.04.019

Mokhtari MS, Rashidi A, Esmailzadeh AK. Estimation of phenotypic and genetic parameters for reproductive traits in Kermani sheep. Small Rumin Res 2010; 88: 27-31. https://doi.org/10.1016/j.smallrumres.2009.11.004

Nagy I, Solkner J, Komlosi I, Safar L. Genetic parameters of production and fertility traits in Hungarian Merino sheep. J Anim Breed Genet 1999; 116: 399-413. https://doi.org/10.1046/j.1439-0388.1999.00204.x

Newton JE, Brown DJ, Dominik S, Van der Werf J. Genetic and phenotypic parameters between yearling, hoggetand adult reproductive performance and age of first oestrus in sheep. Anim. Prod. Sci. 2014, 54(6): 753-761. https://doi.org/10.1071/AN13245

Noguera JL, Varona L, Babot D, Estany J. Multivariate analysis of litter size for multiple parities with production traits in pigs: I. Bayesian variance component estimation. J Anim Sci 2002; 80(10): 2540-2547. https://doi.org/10.1093/ansci/80.10.2540

Olesen I, Perez-enciso M, Gianola D, Thomas DL. A comparison of normal and nonnormal mixed models for number of lambs born in Norwegian sheep. J Anim Sci 1994; 72(5): 1166-1173. https://doi.org/10.2527/1994.7251166x
Posht-e-Masari HA, Shadparvar A, Ghavi Hossein-Zadeh N, Tavatori M. Estimation of genetic parameters for reproductive traits in shall sheep. Trop Anim Health Prod 2013; 45(5): 1259-1263. https://doi.org/10.1007/s11250-013-0357-8

Rahimi SM, Rafat SA, Jafari S. Effects of environmental factors on growth traits in Makuie sheep. Biotechnol Anim Husb 2014; 30(2): 185-192. https://doi.org/10.2298/BAH1402185R

Roehe R, Kennedy BW. Estimation of genetic parameters for LSB in Canadian Yorkshire and Landrace swine with each parity of farrowing treated as a different trait. J Anim Sci 1995; 73(10): 2959-2970. https://doi.org/10.2527/1995.73102959x

Roshanfekr H, Berg P, Mohammadi K, Mohammadi EM. Genetic parameters and genetic gains for reproductive traits of Arabi sheep. Biotechnol. Anim. Husb 2015; 31(1): 23-36. https://doi.org/10.2298/BAH1501023R

Sargolzaei M, Iwaisaki H, Colleau J. CFC: A tool for monitoring genetic diversity. In: Proceeding 8th World Congress on Genetics Applied Livestock Production; Belo Horizonte, Brazil; 2006. pp. 13-18.

Sodiq A, Yuwono P, Santosa SA. Litter Size and lamb survivability of Batur sheep in upland areas of Banjarnegara Regency Indonesia. Anim Prod 2011; 13(3): 166-172.

Vargas Jurado N, Leymaster KA, Kuehn LA, Lewis RM. Estimating heritability of wool shedding in a cross-bred ewe population. J Anim Breed Genet 2016; 133(5): 396-403. https://doi. org/10.1111/jbg. 12215

Vatankhah M, Moradi-Sharebabak M, NejatiJavarami A, Miraei-Ashtiani SR, VaezTorshizi R. A review of sheep breeding in Iran. In: Proceeding of Iranian Conference of Aquatic Animal Science; Tehran, Iran; 2004. pp. 591-597. 
Vatankhah M, Talebi MA. Heritability estimate and correlation between production and reproductive traits in Lori-Bakhtiari sheep in Iran. S Afr J Anim Sci. 2008; 38(2): 110-118. https://doi.org/10.4314/sajas.v38i2.4116

Yadollahi S, Gholizadeh M, Hafezian H. Bayesian inference on genetic parameters for some reproductive traits in sheep using linear and threshold models. J Small Rum Res 2019; 170: 149-153. https://doi.org/10.1016/j.smallrumres.2018.12.001
Yavarifard R, Ghavi Hossein-Zadeh N, Shadparvar A. Estimation of genetic parameters for reproductive traits in Mehraban sheep. Czech J Anim Sci 2015; 60(6): 281-288. https://doi.org/10.17221/8242-CJAS

Yazdi MH, Johansson K, Gates P, Nasholm A, Jorjani $\mathrm{H}$ et al. Bayesian analysis of birth weight and LSB in Baluchi sheep using Gibbs sampling. J Anim Sci 1999; 77(3): 533-540. https://doi.org/10.2527/1999.773533x 